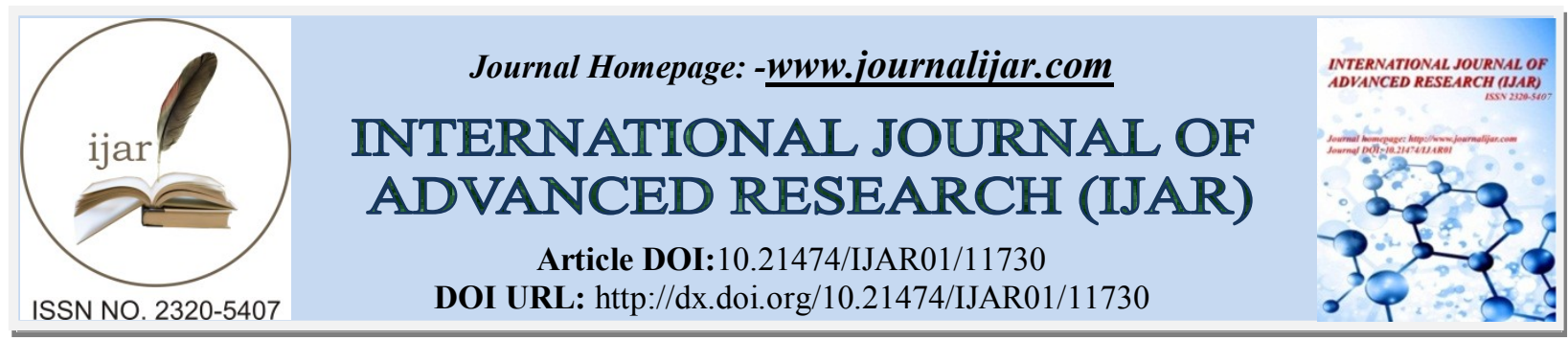

RESEARCH ARTICLE

\title{
TECHNIQUES IN QUANTIFYING HORMONES IN BIOLOGICAL FLUIDS
}

\author{
Nilabja Roy Chowdhury ${ }^{1}$, Md Habib ${ }^{1}$ and Aakanksha Harit ${ }^{2}$ \\ 1. Department of Veterinary Biochemistry, Faculty of Veterinary \& Animal Sciences, West Bengal University of \\ Animal \& Fishery Sciences, Kolkata, West Bengal. \\ 2. Department of Veterinary Parasitology, College of Veterinary Sciences and Animal Husbandry, G B Pant \\ University of Agriculture \& Technology, Pantnagar, Uttarakhand.
}

\section{Manuscript Info}

Manuscript History

Received: 15 July 2020

Final Accepted: 18 August 2020

Published: September 2020

\section{Key words:-}

Hormones, Bio-Assays, Radio-Assay,

Non-Radioactive Assay,

Chromatography, Spctrophotometer

\section{Abstract}

Diagnosing a disease leads to proper treatment of a patient. Various diseases are occurred due to hormonal dis-balances within the body. Minor shift of the hormonal concentration within the body fluids, account for various physio-metabolic disruptions. This leads to formation of many diseases. So, regular or periodic diagnosis of the hormones within body fluids are very important in a clinical point of view. To quantify hormones within the body fluids there are a no. of ways to perform. The procedures may be of radioactive principles or non-radioactive ones. These may be Enzyme Linked Immunosorbent Assay (ELISA), Radio-immuno-assay (RIA), Spectroscopy etc. Modern techniques like Time resolved fluorescence, chemiluminescence etc. are also there. Besides, previously used bioassays are there for experimental usage within the laboratory. The ultimate goal is to elevate the speed of sample collection, faster diagnosis of the hormones and thus, proper treatment of the patient by the physician.

Copy Right, IJAR, 2020,. All rights reserved.

\section{Introduction:-}

Laboratory measurements are nowadays essential parts of medical diagnostics. In endocrinology, hormonal quantification via various assays are practically indispensable. The hormonal assays are used to monitor various hormonal concentration within the body fluid and helps for the further therapeutic success by a physician. The responsibility of the doctor, who is treating a patient is essential to first choose the correct parameters on which the assays are need to be done as he is responsible for the selection and interpretation of various hormonal parameters according to the laboratory results during the patient care. During the last two decades, quantificational assays of various endocrinological parameters have undergone in much popularity and have undergone a massive revolutionary advancement in several ways. In this study, procedures of hormone estimations using body fluids (serum/plasma/whole blood/CSF) are being described.

\section{Bioassays}

These were the first available procedures to quantify hormonal concentrations in body fluids. One among the first example was to measure human growth hormone concentration using the growth of the proximal epiphyseal cartilage of the hypophysectomised femurs in case of rat models ${ }^{1}$. Nowadays, these are only used in two fields:

1. In case of Hormone preparation standardisation. Specifically, International Reference Preparation (IRP) for Recombinant Growth Hormone preparation ${ }^{2}$ and for the leptins ${ }^{3}$. These reference values are used by the World 
Health Organisation. Bioassays are side by side used with Protein Micro-sequencing, Mass spectrometry, Chromatography (specifically, High Performance Liquid Chromatography) and the immunoassays like ELISA and RIA and the values from all the methods are being statistically cumulated and averaged to construct the reference values.

2. In case of relating and estimating the biological activities of certain hormones in the individual's serum. A major breakthrough happened when an automatic cell counter measured the bio-activity of Human Growth Hormone utilising the Proliferative Assay technique on Nb2 lymphoma cells of rats, which peaked to a precision comparable to that of the best of the Immuno-assay techniques like RIA ${ }^{4}$.

\section{Radioreceptor Assays}

Also known as RRA's, these assays look for the specific binding of hormones to a cytoplasmic receptor (for steroid hormones and thyroxines) or membrane receptors (for protein, peptide and glycoprotein hormones). The Bioassay technique uses the bio-activity of a hormone to quantify the hormones but the RRAs uses the binding capability of a specific hormone only and thus it is comparable to that of the immuno-assays ${ }^{5}$. In this method, lymphocytes are targeted as they are easy to analyse ${ }^{6}$. The only con is that the binding of hormones to a receptor is much weaker than that of the binding with its specific antibody ${ }^{7}$. In case of Growth Hormone (GH) estimation, presence of GH-binding proteins cause disturbances for the RRA estimate. RRAs also can be used to estimate the binding potential of Synthetic Steroidal Hormones and their analogues ${ }^{8}$.

\section{Immuno-functional Assays}

This method implies the binding of specific ligand to its specific binding sites and subsequent recognition of the phenomenon with Monoclonal Antibodies (MAbs) for quantitative determination (e.g. in case of Leptins, IGHBP-3, GH etc. $)^{9-11}$

\section{In Situ Methods}

Labelled antibodies and sandwich models are used to detect immobilised antigens obtained from immunohistochemistry, cytochemistry and blotting studies (western blot, dot blot)onto carrier membranes in electrical fields ${ }^{5}$. As this is much time-consuming procedure, it is generally avoided in case of hormonal estimations.

\section{Immunoassays}

\section{Radio-immunoassay (RIA)}

Radioactivity is being used in this procedure for estimation of a particular hormone on the basis of antigen-antibody complex (Ag-Ab complex) production. The procedure requires a tracer hormone (the same hormone which is needed to be studied, attached/tagged with a radio-isotope) and a binding protein ${ }^{12}$.

Certain concentrations of Tracer Hormones and binding proteins (antibody against the specific hormone to be quantified) are mixed with the sample (serum/plasma/ CSF). After incubation of the mixture, competition between the tracer hormone and the hormone (within the sample) is followed by.The higher the quantity of the actual hormone, the greater its binding ability to the binding proteins within the mixture, overcoming the tracer hormone and vice-versa.

After a certain time, the tracer hormones (bound to the antibody) are separated which is followed by the counting of radioactivity, compared with the values of the standard and then the hormonal concentration is calculated. These can be of two types: Competitive and Non-competitive.

\section{Competitive vs Non-competitive assay}

Competitive RIA works on the basis of competitive reaction between a pre-determined/selected amount of radioactive tagged antigen $\left(\mathrm{I}^{125}[\mathrm{Ag}]\right)$ and an unknown concentration of 'cold' antigen with a limited no. of binding proteins or the antibodies $(\mathrm{Ab})$ within the sample ${ }^{5}$.

Separation of the unbound components is done by precipitation and centrifugation of the $\mathrm{Ag}$ - $\mathrm{Ab}$ complex accompanied by a secondary Ab and Polyethylene Glycol, which is mainly used as a precipitation catalyst in the procedure. In competitive assay, the primary concentration of the Ag in the sample is inversely proportional to the bound radioactivity ${ }^{5}$ (Fig: 1a \& 1b).

As the availability of one of the components is limited, competitive assays are more labile than the non-competitive 
with respect to the purity of the labelled Ag's and Ab's and thus, competitive assays are more prone to give inferior results due to occurrences of cross-reactions and non-specific binding activities.

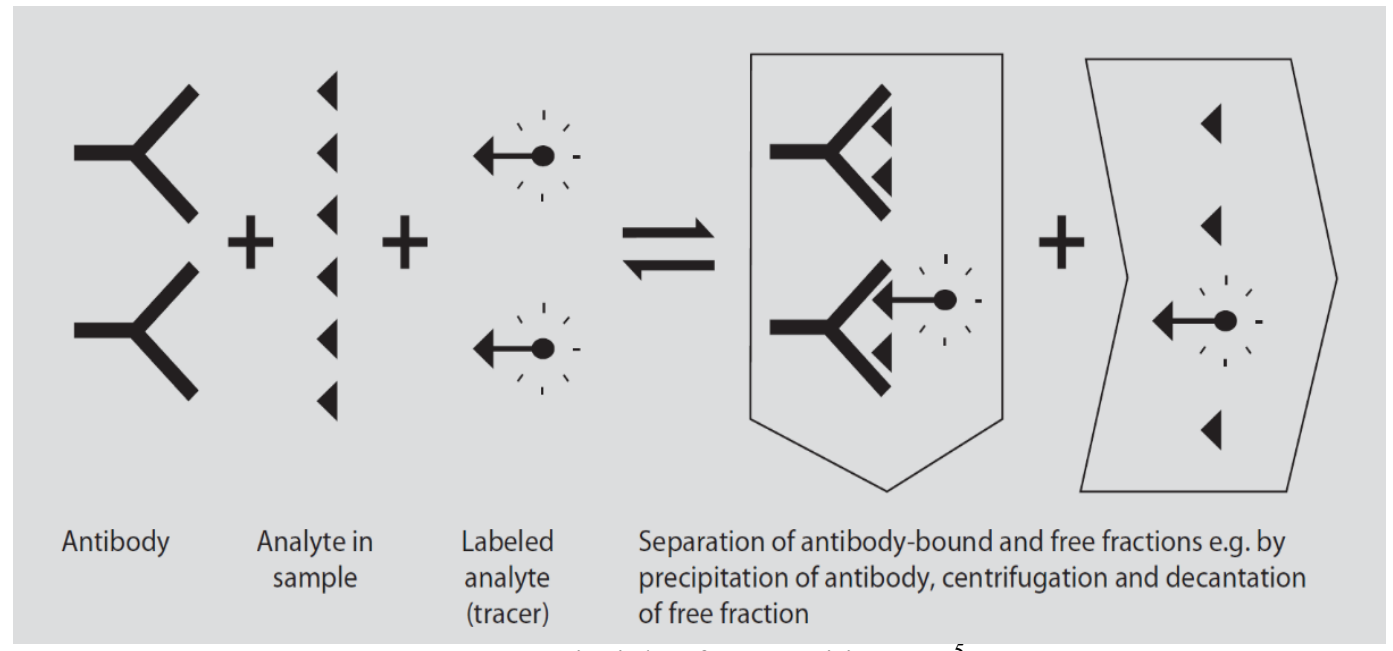

Fig 1a:- Principle of Competitive RIA .

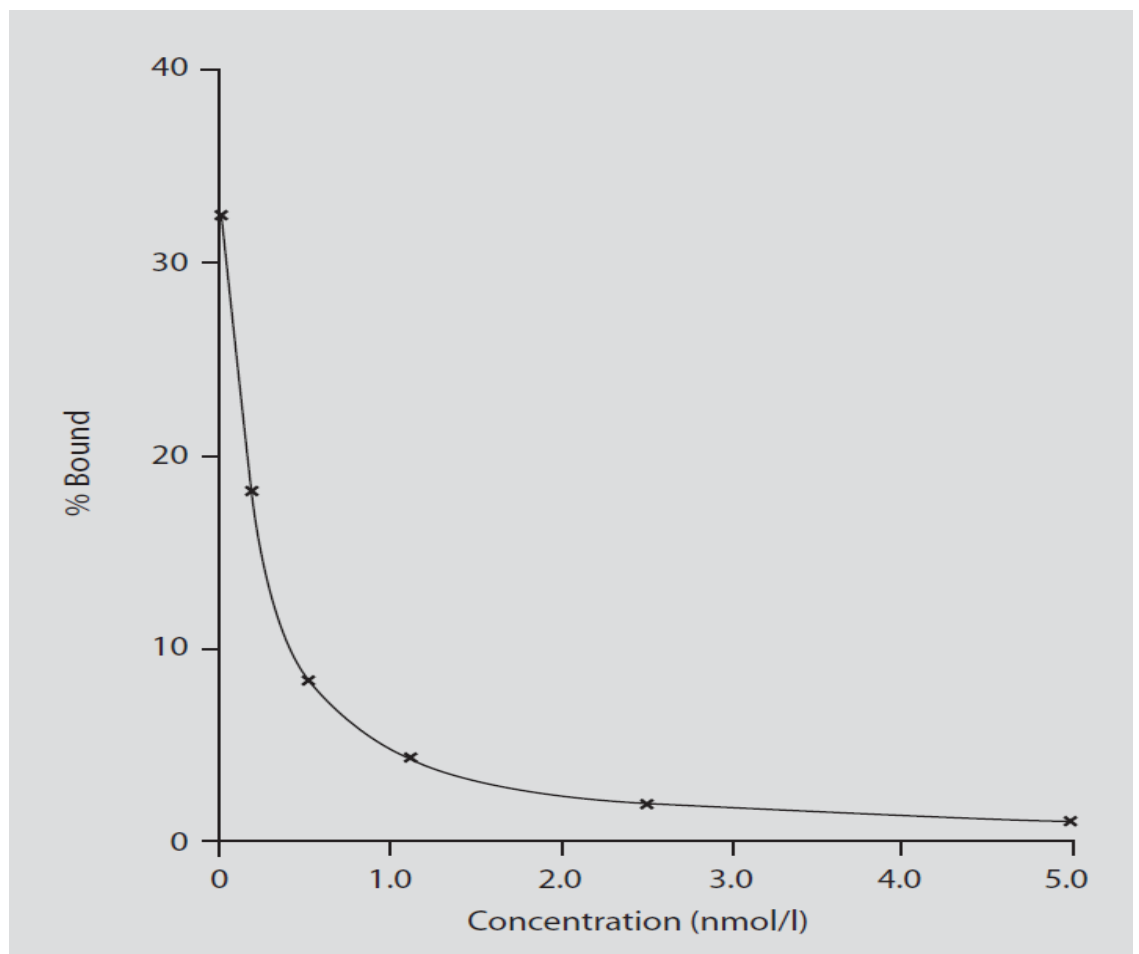

Fig 1b:- Dose-response curve of Competitive RIA ${ }^{5}$.

Miles and Hales developed non-competitive (single-site) immunoradiometric assays, which used labelled antibodies ${ }^{13}$. A marginal surplus of radioactive antibodies $\left(\mathrm{I}^{125}[\mathrm{Ab}]\right)$ reacts with the Ag present in the sample. All unsaturated radio-labelled antibodies are fully made to bind the Ag's fixed to the solid phase and then measured.

Two site immunometric assays (Fig: $2 \mathrm{a} \& 2 \mathrm{~b}$ ) are based on the fact that an antigen has multiple epitopes to bind with an antibody. The Ag binds to the immobilised Ab, separated and then again labelled with secondary antibody for detection. This procedure is much more effective than RIA. Though the main con is the 'high dose hook effect', sometimes occurring in the binding curve of the technique, majorly depended on the quality of the antibodies used in this technique. 


\section{Coated-tube Assay}

In this assay, the primary antibody is directly fixed upon the reaction tube. This technique shortens the separation steps and their timings. This also reduces the total costs of the total technique. The only con is that the tracer hormone needed in this technique is of much more amount than the amount used in competitive RIA. The bound radioactivity is proportional to the antigenic concentration in this technique.
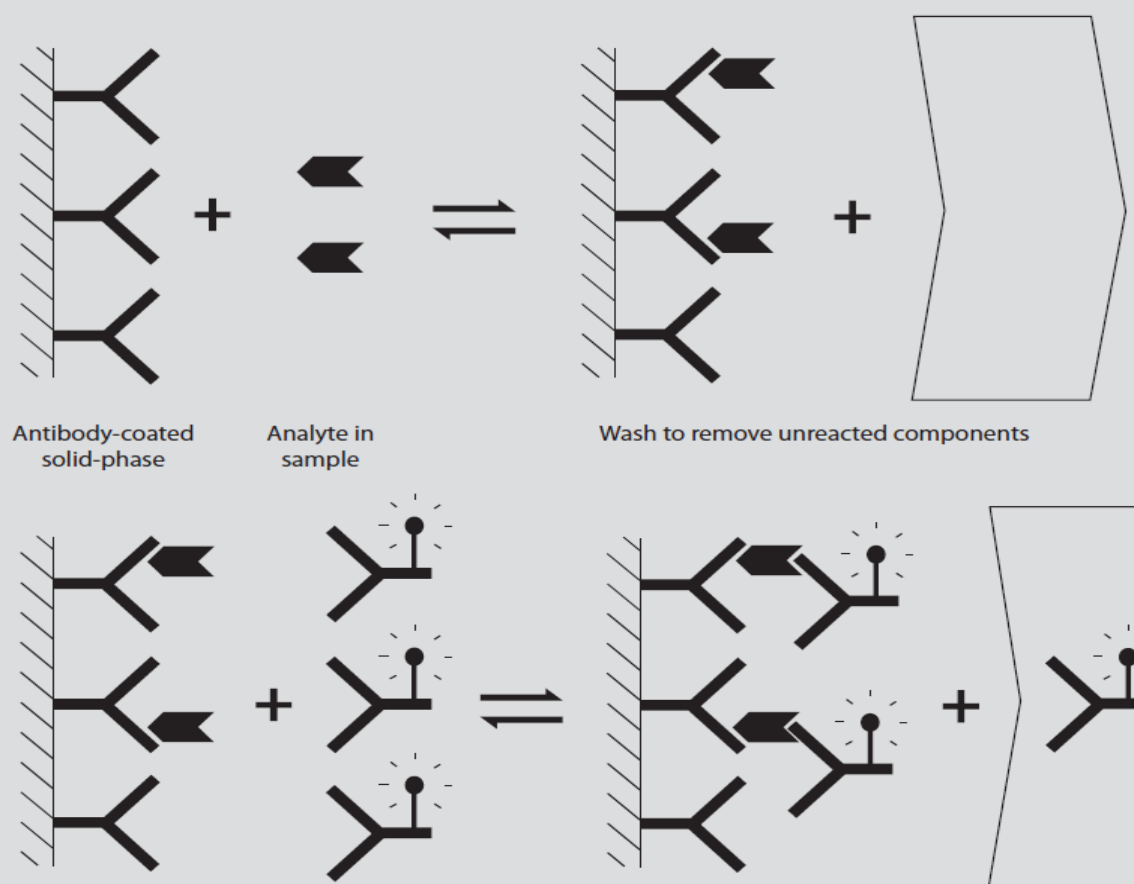

Analyte in

Wash to remove unreacted components sample
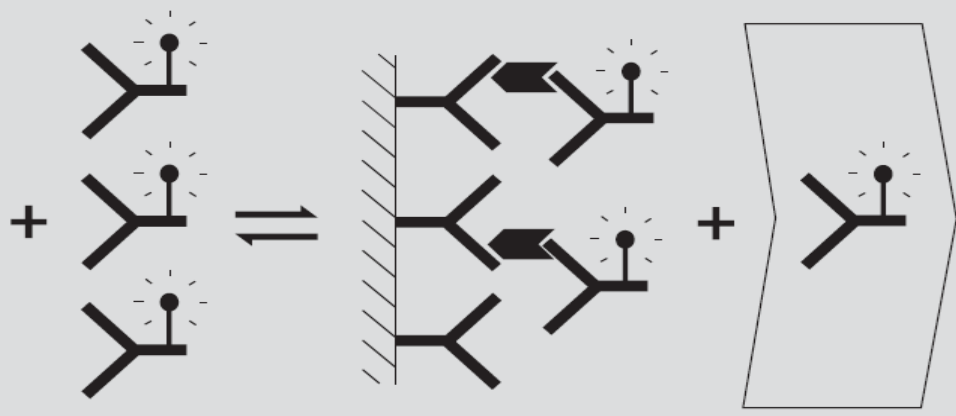

a

Labeled antibody

Wash/aspirate

Fig: 2a:- Principle of IRMA ${ }^{5}$.

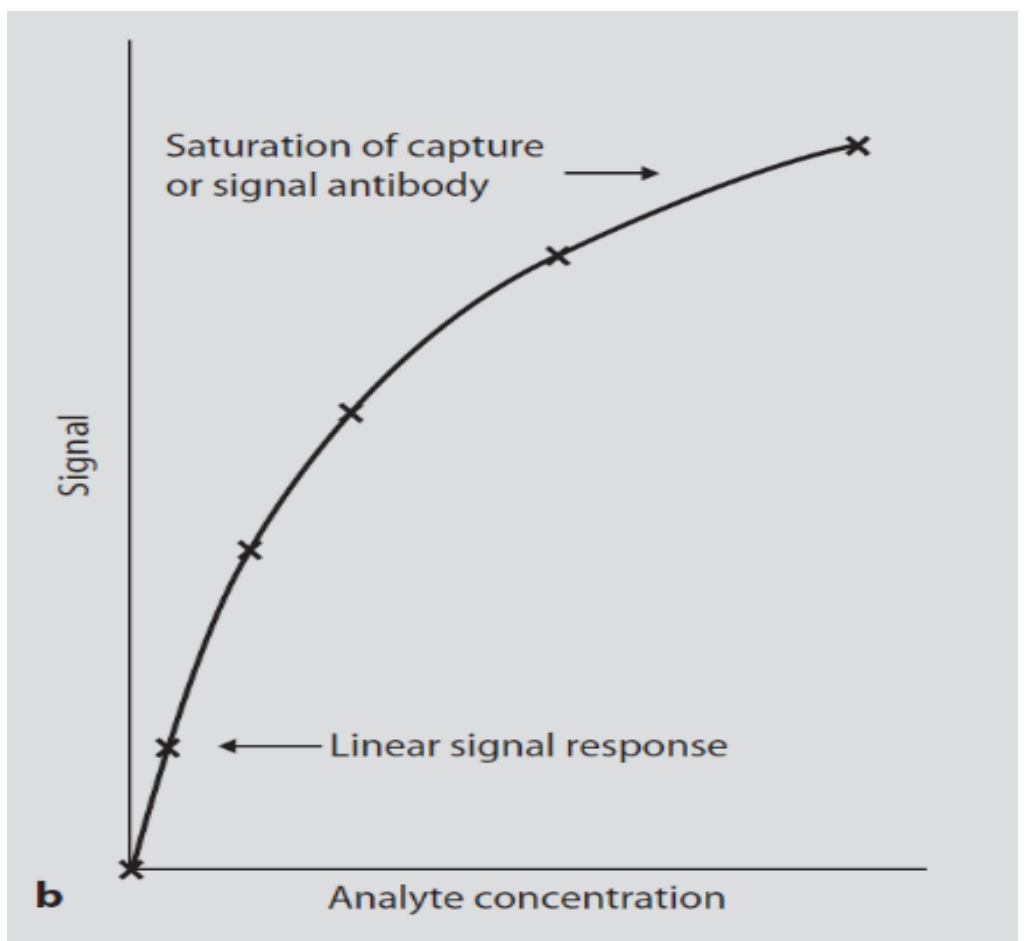

Fig 2b:- Dose dependent curve of IRMA ${ }^{5}$. 


\section{Enzyme Linked Immunosorbent Assay (ELISA)}

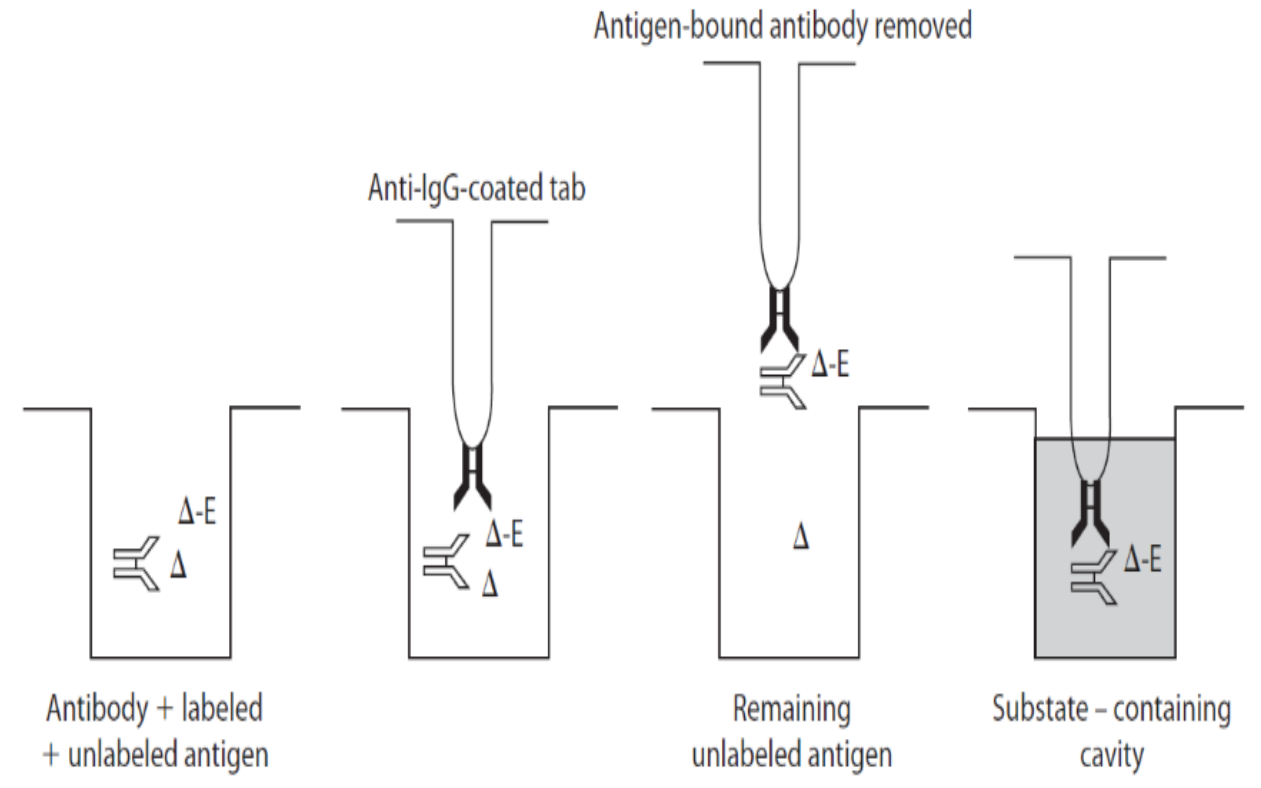

Fig 3:- Principle of Microtiter-tab ELISA ${ }^{5}$.

This method also uses $\mathrm{Ag}-\mathrm{Ab}$ reaction but without any usage of radio-active materials. Conjugated hormones (with enzyme like Hose-radish peroxidase mainly) and respective $\mathrm{Ab}$ are taken into play. As the conjugated hormones and $\mathrm{Ab}$ 's are mixed with the sample, forming of Ag-Ab complex and quantified by the chemiluminescence formed due to the reaction between the enzyme (conjugated with the hormone) and suitable chromogen. Sandwich ELISA is the best technique to quantify hormones in biological fluids like serum, CSF, urine etc. ${ }^{12}$ Nowadays, Lateral Flow Immunoassay Tests are being used where rapid $\mathrm{Ag}-\mathrm{Ab}$ reactions are visualised in a test strip. It is based on sandwich ELISA technique. Estimation of hormones like Human Chorionic Gonadotropin (HCG), Relaxin etc. are being estimated qualitatively ${ }^{14,15}$ (Fig: 4).

\section{Multiplex Techniques for Hormone Analysis}

This is currently a major trend in laboratory diagnostic techniques for delivering maximum nos. of reports in a minimum time. One multiplex panel can perform numerous tests (up to thousands) at one $\mathrm{go}^{5}$. This also includes miniaturisation of the test kits and sample volume to reduce invasiveness. Usage of systems like Gyros disc formate micro-capillary system for this miniaturisation procedure (Fig 4). Classical Ag-Ab interaction procedures are made used of in here (main Doc)

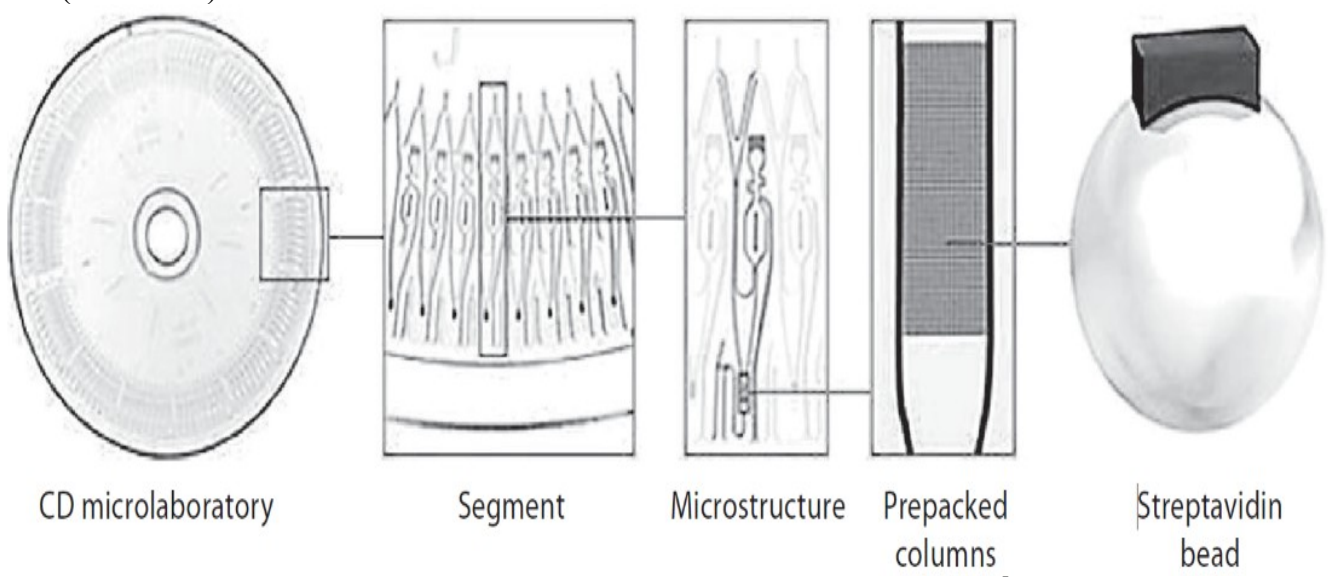

Fig 4:- Gyros disc formate micro-capillary system ${ }^{5}$.

Besides, immobilised DNA, RNA or aptamers are also used. The multiplex systems are not yet available for wide 
usage till date due to the interference among various types of Ab's used in the same system which can lower the specificity and sensitivityOther non-radioactive detection techniques

The following techniques are mentioned with the help of a table mentioned below

\begin{tabular}{|c|c|c|c|c|}
\hline & Colorimetry & Direct Fluorometry & $\begin{array}{l}\text { Chemiluminesc } \\
\text { ence }\end{array}$ & Time-resolved fluorescence \\
\hline $\begin{array}{l}\text { Princ } \\
\text { ipal }\end{array}$ & $\begin{array}{l}\text { Enzyme-bound } \\
\mathrm{Ag} \text { competes } \\
\text { forthe Ab-binding } \\
\text { siteend- } \\
\text { pointspectrophoto } \\
\text { metryofcolour } \\
\text { strength. }\end{array}$ & $\begin{array}{l}\text { - Comparable to } \\
\text { RIA.fluorophores } \\
\text { (fluorescein, rhodamine) } \\
\text { - Act directly as labels } \\
\text { orareenzymaticallyproduced. } \\
\text { Fluorescenceis measured }\end{array}$ & $\begin{array}{l}\text { Light emission } \\
\text { in thecourse of a } \\
\text { chemicalreaction } \\
\text { catalysedbyan } \\
\text { enzyme. }\end{array}$ & $\begin{array}{l}\text { Delayed measurementof the } \\
\text { emitted light fromthe excited } \\
\text { fluorophoreuse of lanthanides } \\
\text { withextremely large stokes'shift, } \\
\text { decay times andquantum yields } \\
\text { (e.g. } \\
\text { Europium) }\end{array}$ \\
\hline $\begin{array}{l}\text { Assa } \\
\text { y } \\
\text { form } \\
\text { at } \\
\text { and } \\
\text { type }\end{array}$ & $\begin{array}{ll}\text { - } & \text { Manual or } \\
\text { automatedELI } \\
\text { SA } \\
\text { - Tab-ELISA }\end{array}$ & $\begin{array}{ll}\text { - } & \text { Automated assay } \\
\text { - } & \text { ELISA }\end{array}$ & Automated assay & $\begin{array}{ll}- & \text { DELFIA system as } \\
& \text { automated assay } \\
- & \text { Manual microtiterplate assay }\end{array}$ \\
\hline $\begin{array}{l}\text { Subst } \\
\text { rates }\end{array}$ & $\begin{array}{l}\text { - 2,2'- azino-bis - } \\
\text { ethylbenzothiaz } \\
\text { oline-6- } \\
\text { sulfonate } \\
\text { (ABTS) } \\
\text { - O- } \\
\text { phenylenediami } \\
\text { ne (OPD) } \\
\text { - 3,3',5,5'- } \\
\text { tetramethylbenz } \\
\text { idine } \\
\text { (TMB) }\end{array}$ & $\begin{array}{l}\text { 4-methylumbelliferyl phosphate } \\
\text { stimulation with light of } 365 \mathrm{~nm} \\
\text { wavelength,emission at } 448 \\
\text { nm(measurement of theStokes' } \\
\text { shift) }\end{array}$ & $\begin{array}{l}\text { Adamantyl 1,2- } \\
\text { dioxetane or } \\
\text { simultaneousoxi } \\
\text { dation of } \\
\text { tripopylaminean } \\
\text { druthenium-ii. }\end{array}$ & None \\
\hline $\begin{array}{l}\text { Sensi } \\
\text { tivity } \\
\text { Or } \\
\text { Rang } \\
\text { e }\end{array}$ & $\begin{array}{ll}- & \text { Rangeofspec } \\
\text { trophotomet } & \text { er: } 2.0 \text { OD } \\
\text { - } & \text { Peroxidase- } \\
& \text { based assays } \\
\text { more sensitive }\end{array}$ & $\begin{array}{l}\text { Higher sensitivity than } \\
\text { colorimetry with repeated } \\
\text { photomultiplication }\end{array}$ & $\begin{array}{ll}\text { - } & \text { High } \\
\text { - } & \text { Sensitivity } \\
& \text { Wide range }\end{array}$ & $\begin{array}{ll}\text { - } & \text { High sensitivity } \\
\text { - } & \text { Wide range }\end{array}$ \\
\hline Pros & $\begin{array}{ll}- & \text { Robust } \\
\text { - } & \text { Simple }\end{array}$ & High sensitivity & $\begin{array}{ll}\text { - } & \text { Minimal } \\
\text { background } \\
\text { - } & \text { Quick signal } \\
\text { generation } \\
\text { - } & \text { High } \\
\text { specific } \\
\text { activity } \\
\end{array}$ & $\begin{array}{l}\text { Delayed } \\
\text { measurementminimizesinterferen } \\
\text { cefromfluorescentmolecules } \\
\text { within thesample }\end{array}$ \\
\hline Cons & Narrow range & $\begin{array}{l}\text { Interference of } \\
\text { thefluorescencewithbackground } \\
\text { fluorescenceandquenching }\end{array}$ & $\begin{array}{l}\text { Only for } \\
\text { automatedsyste } \\
\text { ms }\end{array}$ & Not known \\
\hline
\end{tabular}

Table 1:- Non-radioactive hormonal estimation techniques.

\section{Conclusion:-}

Hormone estimation in body fluids is definitely a great tool for a physician to estimate the metabolic problems of the body of a patient. Not only that, these estimations can help to diagnose pregnancy too. Various procedures and 
techniques have evolved to quantify different hormones. Immunoassays (like ELISA, RIA), colorimetry, spectrofluoroscopy, multiplex systems are being used. Multiplex systems are the upcoming way-outs to deliver quality results in minimum time. Miniaturisation of the techniques are also being done for fitting up several multiplex assay systems in a certain place for even faster approaches. New assays on automated platforms are the future in this field to massively elevate the analytical menus. The singleplex and multiplex assays are being improved simultaneously for the betterment of the human and animal health. Other types of body fluids (like saliva) are also being taken into considerations for more non-invasive approaches for faster sample collection. Afterall, it can be concluded that clinical diagnosis can be accompanied by refined and full-proof laboratory diagnosis for the ultimate benefit of the human and animal health.

\section{Reference:-}

1. Evans HM, Simpson ME, Marx W, Kibrick E. Bioassay of the Pituitary Growth Hormone. Width Of The Proximal Epiphysial Cartilage Of The Tibia In Hypophysectomised Rats 1 , 2. Endocrinology. 1943;32(1):1316. doi:10.1210/endo-32-1-13

2. Bristow AF, Munk Jespersen A. The Second International Standard for Somatropin (Recombinant DNAderived Human Growth Hormone): Preparation and Calibration in an International Collaborative Study. Biologicals. 2001;29(2):97-106. doi:10.1006/biol.2001.0281

3. Robinson C, Gaines Das R, Woollacott D. The first international standard for human leptin and the first international standard for mouse leptin: comparison of candidate preparations by in vitro bioassays and immunoassays. J Mol Endocrinol. August 2001:69-76. doi:10.1677/jme.0.0270069

4. Binder G, Benz MR, Elmlinger M, Pflaum C-D, Strasburger CJ, Ranke MB. Reduced human growth hormone (hGH) bioactivity without a defect of the GH-1 gene in three patients with rhGH responsive growth failure. Clin Endocrinol (Oxf). 1999;51(1):89-95. doi:10.1046/j.1365-2265.1999.00744.x

5. Elmlinger MW. Laboratory Measurements of Hormones and Related Biomarkers: Technologies, Quality Management and Validation. 2011:1-31.

6. Kiess W, Butenandt O. Regulation of GH Binding to Specific Cellular Receptors In Vitro - A New Model of Growth Regulation In Vivo. HormMetab Res. 1987;19(04):171-176. doi:10.1055/s-2007-1011770

7. BAUMANN G. Growth Hormone Binding Proteins and Various Forms of Growth Hormone: Implications for Measurements. Acta Paediatr. 1990;79(s370):72-80. doi:10.1111/j.1651-2227.1990.tb11677.x

8. Asai D, Shimohigashi Y. [The assessment of xenoestrogens by competitive receptor binding assays]. Nihon Rinsho. 2000;58(12):2486-2490.

9. Strasburger CJ. Immunofunctional assay of human growth hormone $(\mathrm{hGH})$ in serum: a possible consensus for quantitative hGH measurement. J Clin Endocrinol Metab. 1996;81(7):2613-2620. doi:10.1210/jc.81.7.2613

10. Lammert A, Kiess W, Bottner A, Glasow A, Kratzsch J. Soluble Leptin Receptor Represents the Main Leptin Binding Activity in Human Blood. BiochemBiophys Res Commun. 2001;283(4):982-988. doi:10.1006/bbrc.2001.4885

11. Lassarre C. Use of the Ligand Immunofunctional Assay for Human Insulin-Like Growth Factor (IGF) Binding Protein-3 (IGFBP-3) to Analyze IGFBP-3 Proteolysis and IGF-I Bioavailability in Healthy Adults, GHDeficient and Acromegalic Patients, and Diabetics. J Clin Endocrinol Metab. 2001;86(5):1942-1952. doi:10.1210/jc.86.5.1942

12. Mahapatra ABS. Essentials of Medical Physiology. Third Edit. Kolkata: Current Books International; 2008.

13. MILES LEM, HALES CN. Labelled Antibodies and Immunological Assay Systems. Nature. 1968;219(5150):186-189. doi:10.1038/219186a0

14. Hamad EM, Hawamdeh G, Jarrad NA, Yasin O, Al-Gharabli SI, Shadfan R. Detection of Human Chorionic Gonadotropin (hCG) Hormone using Digital Lateral Flow Immunoassay. In: 2018 40th Annual International Conference of the IEEE Engineering in Medicine and Biology Society (EMBC). IEEE; 2018:3845-3848. doi:10.1109/EMBC.2018.8513355

15. Liu C-C, Yu J-S, Wang P-J, et al. Development of sandwich ELISA and lateral flow strip assays for diagnosing clinically significant snakebite in Taiwan. Sanchez E, ed. PLoSNegl Trop Dis. 2018;12(12):e0007014. doi:10.1371/journal.pntd.0007014. 